\title{
Música, afeto e política dos corpos no New Queer Cinema de Karim Aïnouz
}

\section{Music, affection and body politics in Karim Aïnouz's New Queer Cinema}

Guilherme Maia ${ }^{1}$, Everaldo Asevedo² de pós-graduação em Comunicação e Cultura Contemporâneas da Ufba. É autor do livro Elementos para uma poética da música dos filmes (Appris, 2015) e coorganizador dos livros Ouvir o documentário: vozes, música e ruídos (Edufba, 2015) e O cinema musical na América Latina: aproximações contemporâneas (Edufba, 2018). E-mail: maia.audiovisual@gmail.com. da Ufba, bacharel em Artes, com concentração em Cinema e Audiovisual, da mesma universidade e bacharel em Direito pela Universidade Católica do Salvador. Atualmente, desenvolve projeto de pesquisa intitulado "Sexualidade e heroísmo no cinema gay de Karim Aïnouz: as jornadas dos protagonistas de Madame Satã e Praia do Futuro". E-mail: everaldoasevedo@gmail.com. 


\section{Resumo}

Utilizando o conceito de valor acrescentado, tal como proposto por Michel Chion, e estudos recentes sobre o uso de música nos filmes como mediadores teórico-metodológicos, este artigo analisa os projetos musicais de dois longas-metragens protagonizados por personagens gays dirigidos por Karim Aïnouz: Madame Satã (2002) e Praia do Futuro (2014). O processo analítico nos conduziu à conclusão de que nas duas obras a música, especialmente a canção popular, opera aderida aos encontros e desencontros amorosos dos protagonistas, e presta reverência aos ideais de representação de personagens homossexuais defendidos pelo New Queer Cinema.

Palavras-chave

Cinema brasileiro, música, análise fílmica, New Queer Cinema.

\section{Abstract}

By using the concept of added value proposed by Michel Chion, and verifying recent studies on the use of music in films as theoreticalmethodological mediators, this article analyzes the musical projects of two films starring gay characters directed by Karim Aïnouz: Madame Satã (2002) and Praia do Futuro (2014). Analysis showed that music, especially popular songs, operates in conjunction with the protagonists' amorous encounters and mismatches reverently to the ideals of representation of homosexual characters defended by New Queer Cinema.

\section{Keywords}

Brazilian Cinema, music, film analysis, New Queer Cinema 
Desde o início de sua carreira como diretor, em 1993, com o lançamento do curta metragem Seams, o brasileiro Karim Aïnouz dirigiu cinco longas-metragens de ficção exibidos comercialmente (KARIM..., [2019])³, obras que lhe possibilitaram conquistar reconhecimento como um dos mais importantes diretores do cinema brasileiro contemporâneo, com expressiva participação e premiação em festivais nacionais e internacionais.

Nascido em Fortaleza, em 1966, Aïnouz mudou-se, em 1989, para Nova Iorque, onde iniciou um mestrado em Teoria do Cinema na New York University. Nessa época, teve contato com o movimento que viria a ser cunhado por B. Ruby Rich como New Queer Cinema, surgido em contraposição à difusão de uma cultura de representação de personagens homossexuais no cinema. Consolidada a partir de meados da década de 1970 como resposta à vilanização da comunidade gay em plena crise da aids e forma de aproximação dessa comunidade do modelo heteronormativo vigente, esse modelo partia da ideia de que "lésbicas e gays deveriam enquadrar-se em modelos considerados mais aceitáveis e palatáveis para a sociedade como um todo, para, por consequência, serem aceitos por ela como iguais" (LACERDA, 2015, p. 123). Já o New Queer Cinema buscou se estabelecer como um mo(vi)mento cinematográfico oriundo do desejo de diversos realizadores de reconfigurar a representação desses personagens, "fazendo algo novo, renegociando subjetividades, anexando gêneros inteiros, revisando histórias em suas imagens" (RICH, 2015, p. 18). Pretendiam, dessa forma, celebrar a identidade queer defendida pelos teóricos e movimentos ativistas LGBTQI+ do final da década de 1980 e início de 1990, "que rechaçava o caráter assimilacionista [...], abraçando, ao invés disso, o orgulho pela diferença e pelo seu caráter transgressor em relação à norma" e buscava ressignificar "estereótipos considerados incômodos e insuflando-os com agência e empoderamento" (LACERDA, 2015, p. 124). Nesse contexto, os dois filmes de Karim Aïnouz protagonizados por personagens gays Madame Satã (2002) e Praia do futuro (2014) - são o objeto deste artigo, 
que se propõe a analisar o modo como o diretor cearense utiliza a música em seu cinema New Queer.

Filmado em locação no bairro da Lapa, no Rio de Janeiro, Madame Satã aborda a vida de João Francisco dos Santos, que viria a ser conhecido como a célebre personagem-título: exímio capoeirista, bom de briga, golpista, gay, negro e pobre. Centrado nos anos anteriores à sua transformação na figura que o tornaria lendário na boemia carioca na década de 1940, o longa-metragem explora, especialmente, a relação de João Francisco com sua família postiça a prostituta Laurita e o gay afeminado Tabu, que ele heroicamente protegia de violências e discriminações - e seu conturbado relacionamento afetivo com Renatinho, outro golpista frequentador dos bares da Lapa, concentrando-se na jornada do protagonista até sua primeira apresentação como Madame Satã. Ao escrever sobre este filme, Chico Lacerda o associa diretamente aos anseios do New Queer Cinema e ao contato que Aïnouz teve com esse movimento em seus anos de formação como realizador audiovisual. Para Lacerda (2015, p. 215), o gesto insubordinado em relação aos códigos de conduta e representação vigentes "pode ser considerado o principal elemento de ligação do filme com o NQC, algo que fica ainda mais claro ao lembrarmos que Karim Aïnouz havia, ele próprio, após um curso de Cinema Studies na New York University, travado contato direto com o movimento". Ainda segundo Lacerda (2015, p. 216), "isso é perceptível especialmente em posturas extremas de ambos os gêneros que coabitam o personagem de João Francisco: por um lado, malandro violento e chefe de família rígido; por outro, dançarina sensual e sofisticada".

Apesar de todo o sucesso com a temática LGBT em seu filme de estreia, somente em 2014, doze anos após Madame Satã, Karim Aïnouz voltaria a lançar um longa-metragem de ficção protagonizado por um personagem homossexual. Praia do futuro foi filmado em Fortaleza, cidade natal do diretor, e em Berlim, cidade em que ele estabeleceu residência, e conta a história de Donato, um salva-vidas que trabalha na Praia do Futuro, localizada na capital cearense. Na primeira cena do filme, Donato fracassa na tentativa de salvar do afogamento um turista alemão, 
o que o leva a conhecer Konrad, o amigo do afogado, com quem se envolve amorosamente. Graças a essa relação ele se muda para Berlim, deixando para trás, no Brasil, a família, especialmente o irmão mais novo, Ayrton. Anos mais tarde, Ayrton surge em Berlim à procura de Donato, e a chegada desse "fantasma" do passado leva o ex-salva-vidas a finalmente enfrentar tudo aquilo de que havia fugido ao longo da vida: a assunção da homossexualidade perante o irmão que o idolatrava, o medo de assumir um compromisso afetivo duradouro com o amigo do homem que não conseguiu salvar, o reconhecimento da própria falibilidade.

Nos dois filmes, Karim Aïnouz parece ter conseguido retratar um espectro da diversidade e da complexidade do homem homossexual, de suas lutas heroicas, externas e internas, para ser e viver sua sexualidade e seus afetos perante sua família e uma sociedade que, normalmente, insiste em agredi-lo, estereotipá-lo, marginalizá-lo. Aïnouz buscou, assim, através das jornadas de João Francisco (protagonista de Madame Satã) e de Donato (protagonista de Praia do futuro), ressignificar as possibilidades de representação de personagens gay em filmes brasileiros, envolvendo suas trajetórias numa aura de relevância simbólica, na tentativa de trazer outros olhares acerca do universo de pessoas que constantemente enfrentam violências e discriminações em razão de sua identidade, expressão de gênero, orientação sexual.

Neste artigo, propomos que a música, operando como valor acrescentado (CHION, 1993) ${ }^{4}$ aos encontros e desencontros amorosos dos protagonistas, é um elemento importante na poética queer de Karim Aïnouz, aderida aos ideais representativos de personagens homossexuais defendidos pelo New Queer Cinema. Aïnouz explorou, em cenas emblemáticas de ambas as produções, embaladas pela potência de canções românticas, momentos de vivência de afeto físico. E a escolha destas canções - "Noite cheia de estrelas" e "Aline" - refletem o recurso à potência afetiva de um cancioneiro romântico, conforme apontado por 
Irene Depetris Chauvin. Para Chauvin (2016, p. 50-51, tradução nossa), a música, especialmente a canção popular romântica, tem uma "poderosa capacidade para expressar, construir, projetar e representar a subjetividade" ${ }^{\prime \prime}$. Isso acontece, segundo a autora, porque a música aciona a memória dos nossos próprios sentimentos, constrói posições de sujeito em relação ao ouvinte e, sobretudo as canções populares, expressam experiências emocionais do eu lírico e mobilizam memórias afetivas no ouvinte.

\section{A história dolorosa desse amor: João Francisco, Renatinho e Celestino em Madame Satã}

Visto como um todo, o projeto musical de Madame Satã se inscreve em uma poética realista, alinhada a princípios defendidos, por exemplo, por Robert Bresson (2005), e ao Voto de castidade do Dogma 95. Para Bresson, a música possível no cinema é somente aquela que o espectador percebe sendo executada na diegese. Isso porque, para ele, a música extradiegética "é um possante modificador e até destruidor do real, como álcool ou droga" (BRESSON, 2005, p. 106). "Nada de música de acompanhamento, de apoio ou reforço. Nada de música de modo algum (com exceção, é claro, da música tocada por instrumentos visíveis)" (BRESSON, 2005, p. 29). Na mesma chave, o realismo proposto por Thomas Vinterberg e Lars von Trier, signatários do Dogma 95, em um dos itens do célebre decálogo, determina: "O som não deve jamais ser produzido separadamente da imagem ou vice-versa. (A música não poderá ser utilizada a menos que ressoe no local onde se filma a cena)"6 (TRIER; VINTERBERG, 1995, tradução nossa).

Madame Satã não adota uma atitude tão radical quanto Bresson e os signatários do manifesto dinamarquês. Na sequência em que João Francisco briga com os seguranças que o impediram de entrar na boate High Life e depois volta para casa de bonde acompanhado por Laurita e Tabu, ouvimos, no plano

No original: "[...] poderosa capacidad de expresar, construir, proyectar y representar la subjetividad". 
extradiegético, a composição instrumental de Bruno Bertoli, "Tango romântico". Interpretado por um conjunto formado por violões, bandolim, violoncelo, contrabaixo e piano, o que ouvimos é um tango dolente, pungente, que fortalece, na chave trágica da piedade, o vínculo afetivo que o filme constrói entre o espectador e o protagonista, que vemos ser barrado no baile por conta de sua má fama, lutar com dois seguranças da casa noturna e voltar para casa com o semblante transmitindo nuances de raiva e tristeza. Durante a luta, o tango de andamento lento, em tonalidade menor, com melodia lacrimosa e tempos em rubato, não adere à agressiva fisicalidade do combate. O jogo audiovisual mais parece querer nos fazer ouvir a voz do filme manifestando o posicionamento políticoafetivo da obra em relação ao seu protagonista.

Em outros momentos, a música transita temporariamente fora da diegese, sendo ancorada, na realidade, na cena seguinte, ou tendo seu início na cena anterior, que é o caso da canção que ouvimos em cenas iniciais do filme, "Nuits d'Alger", chanson francesa composta por Maurice Hermite e Pierre Larrieu, gravada pela primeira vez por Josephine Baker. Depois de ser cantada pela personagem cantora Vitória dos Anjos no palco de um cabaré, segue, em seção instrumental, tecendo nossa adesão afetiva ao personagem em seu trajeto solitário para casa. A música dominante em Madame Satã, contudo, são as muitas canções que emanam de aparelhos, músicos e vozes presentes na cena, em um regime que tende fortemente ao realismo, com protagonismo da canção-tema "Noite cheia de estrelas".

Composta por Cândido das Neves e gravada por Vicente Celestino, em abril de 1932, "Noite cheia de estrelas" está conectada aos tensos encaixes e desencaixes amorosos entre João Francisco e Renatinho. A canção-tema associada ao par romântico será acionada, pela primeira vez, no segundo encontro entre os dois personagens, no quarto de João. A sequência começa quando vemos Renatinho esperando por João Francisco na saída da boate onde o protagonista trabalha. Sob o pretexto de pedir a João que o ensine a jogar capoeira, Renatinho o segue em seu caminho a pé para casa. A ação se constrói, desde o início, marcada pela tensão sexual, mostrada ao espectador por trocas de olhares e sorrisos sedutores 
e pela espectatorialidade voyeurística de uma relação sexual entre Tabu e um de seus clientes através da fresta de uma porta. Já no quarto, no momento em que João Francisco abre a porta de um armário, além dos sons do ambiente externo que vazavam para o interior (latidos de cães, ruídos de veículos, vozerio), passamos a ouvir também uma música instrumental de natureza romântica com estilo e sonoridade de gravações antigas. O protagonista abre a janela, o volume da música que vem de fora aumenta e o ambiente é invadido pela voz de um cantor. Em uma performance repleta de malícia e sedução, o protagonista começa a cantar junto com a gravação, enquanto caminha lentamente na direção de Renatinho (Figura 1).

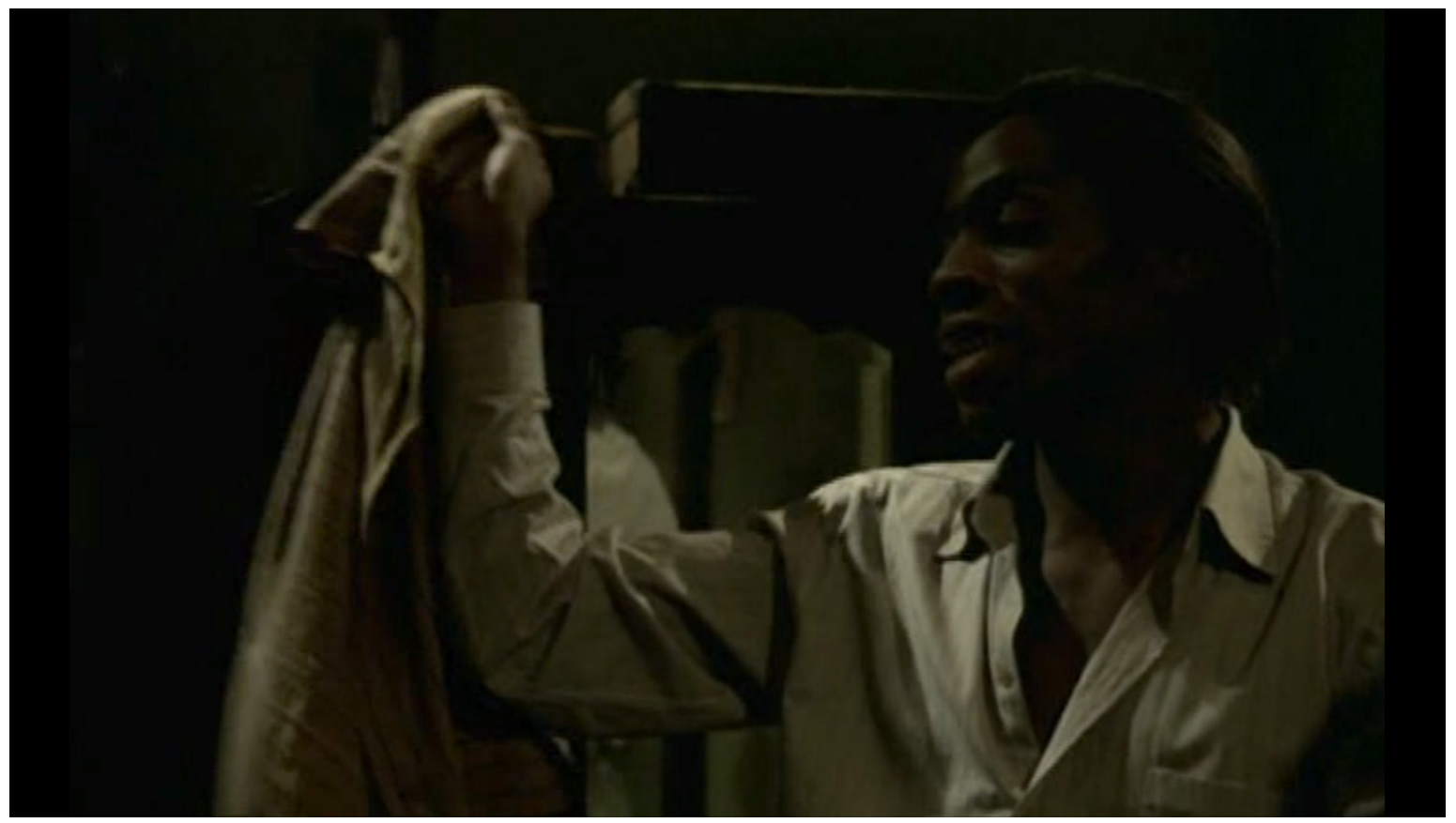

Figura 1: João Francisco canta "Noite cheia de estrelas" para Renatinho Fonte: Madame Satã.

A voz que ouvimos na gravação é de Vicente Celestino, astro da canção popular no Brasil naquele início da década de 1930. "Noite cheia de estrelas" é um tango-canção, espécie de tango que se consolida em Buenos Aires a partir do lançamento de "Mi noche triste", gravado por Carlos Gardel em 1917. Uma das características do tango-canção é o caráter dramático das letras que, via de regra, falam de dores e fracassos amorosos, contam histórias de um homem 
abandonado ou rejeitado pela mulher amada (COLLIER, 2003). Em "Noite cheia de estrelas", o eu lírico fala para uma mulher que não o escuta sobre as dolorosas queixas $^{7}$ de um amor irrealizado.

Após João, agora visto por nós com o rosto bem próximo a Renatinho, cantar os versos "Quero matar meus desejos/ Sufocá-lo com os meus beijos", Renatinho toma a inciativa e dá em João um forte beijo na boca (Figura 2).

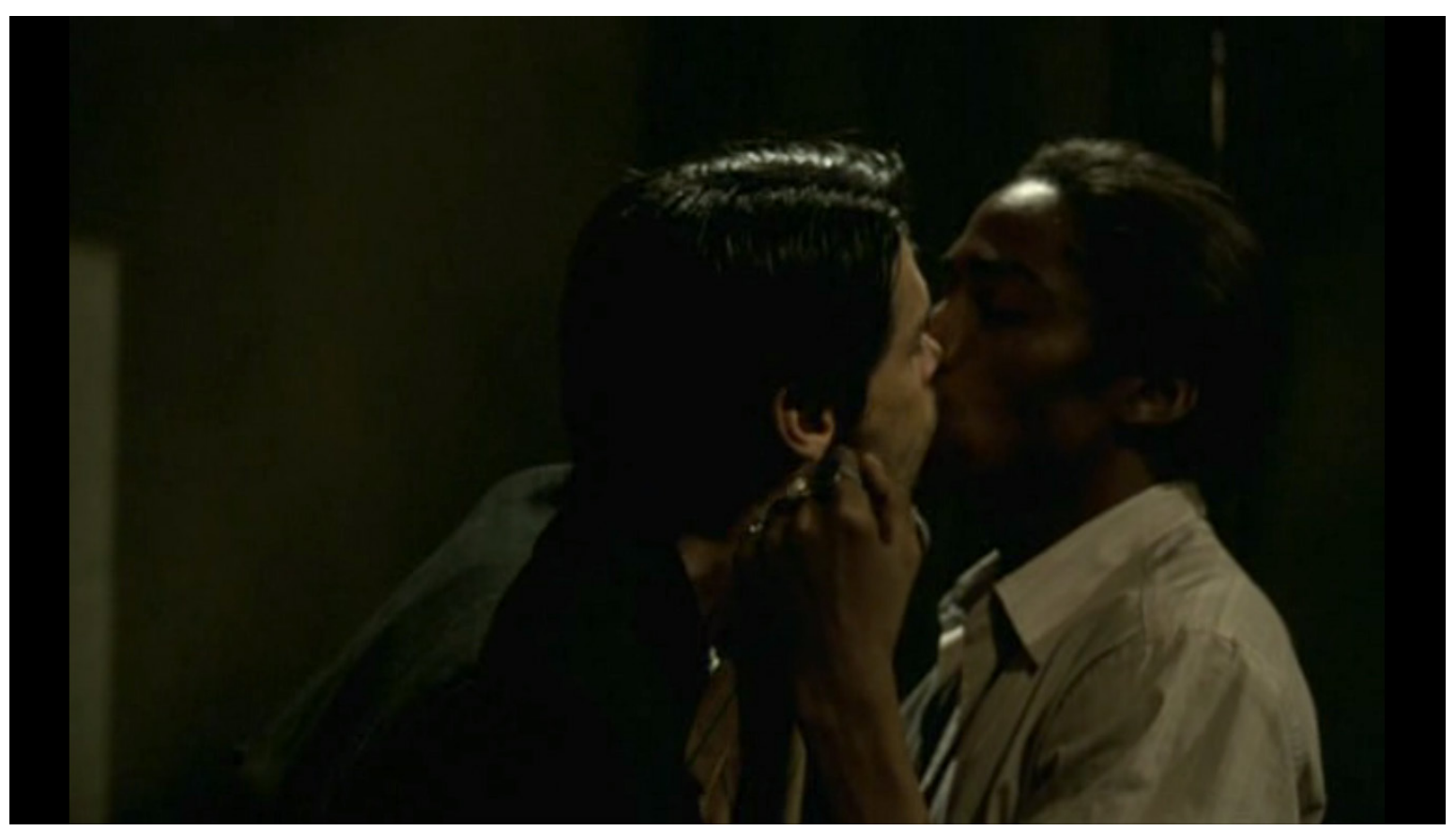

Figura 2: João Francisco beija Renatinho

Fonte: Madame Satã.

João afasta o beijo, e a voz de Celestino segue na trilha sonora enquanto o protagonista, em tom súplice, diz: "Por obséquio, meu curumim, os sinos tocam e a noite chora. Avoa. Por favor, avoa, avoa, avoa. Sai desse mundo devasso e fedorento".

O "curumim", desapontado, tenta insistir, mas João, agora com voz assertiva, manda que ele vá embora. Quando Renato fecha a porta ao sair do quarto, a música é interrompida em corte seco e a tela passa a nos mostrar João sozinho e pensativo em seu quarto pouco tempo depois, acariciando a colcha da cama (Figura 3). 


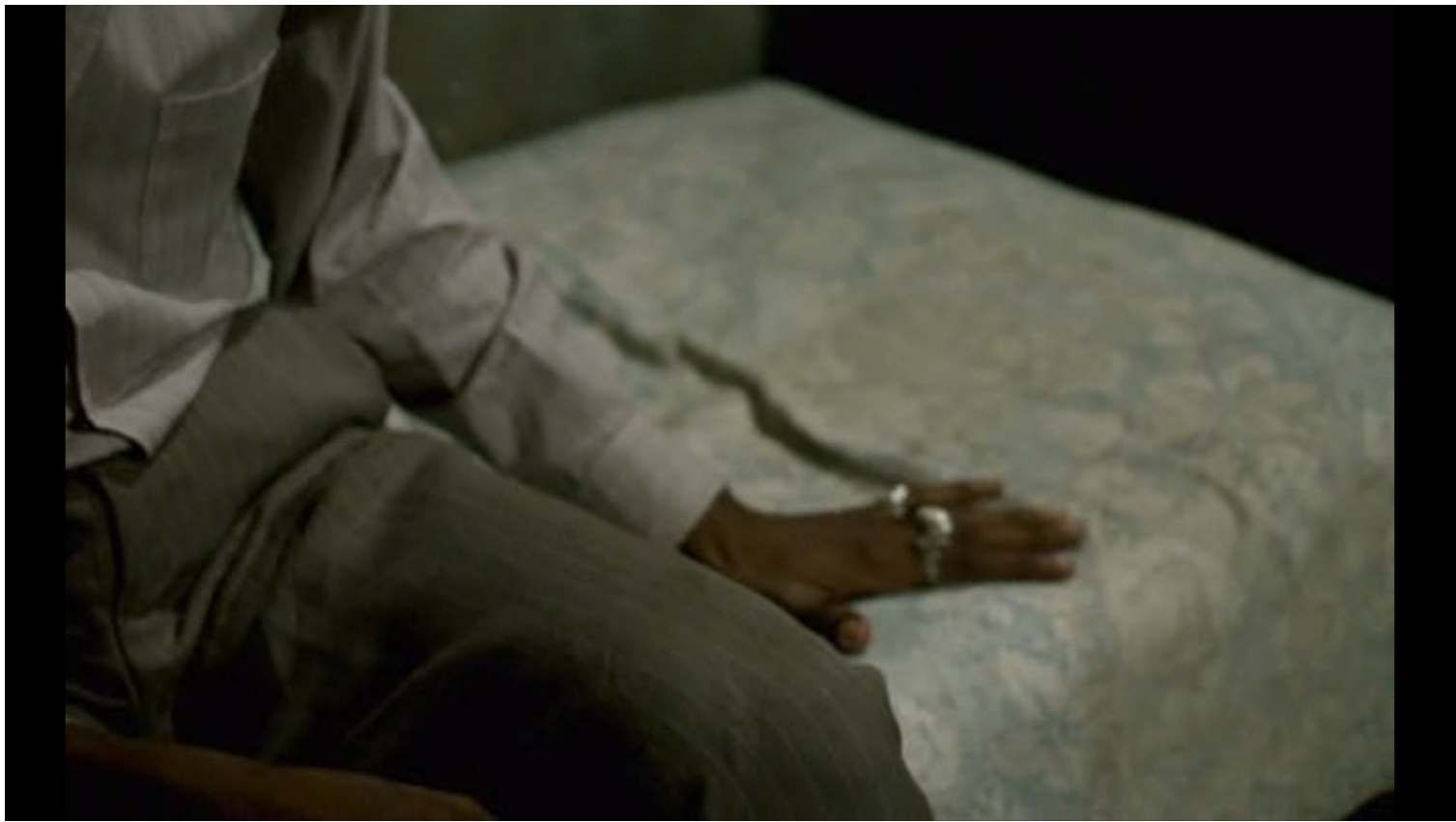

Figura 3: João Francisco após a partida de Renatinho Fonte: Madame Satã.

O que ouvimos e vemos nesta sequência está, de certa forma, em regime de consonância. Cenas de encaixes/ desencaixes amorosos e trocas de afetos corporais acompanhadas por canções românticas são, sabemo-lo todos, um clichê de produções audiovisuais de difusão massiva (filmes, ficção seriada para TV, publicidade etc.), estratégia usada pelos melodramas em bases regulares e, igualmente, em muitos daqueles que Bordwell (1985) classificou como filmes de arte e ensaio. Além disso, como o filme confirmará mais adiante, a trama entre o protagonista e seu "curumim" é, como diz a canção, uma história dolorosa, uma relação tensa, permeada por conflitos e agressividade viril, com final trágico. Observemos, ainda, que, na montagem, o verso "sufocá-lo com meus beijos" antecede precisamente o momento em que o beijo acontece, em um comentário literal que interrompe o canto amador.

Da mesma forma, música aplicada como signo de tempo e lugar - o Rio de Janeiro do início da década de 1930 - é estratégia largamente empregada no reino dos produtos audiovisuais. As canções utilizadas em Madame Satã composições de autores como Ismael Silva, Lamartine Babo, Ary Barroso e Noel 
Rosa - delatam um compromisso do filme com uma representação realística da paisagem radiofônica do tempo histórico. A canção que ouvimos na cena ora em análise carrega, em sua textura, as "marcas do seu tempo" - a sonoridade da gravação, o parnasianismo da letra, o cantar empostado de Celestino. A variante importante, aqui defendemos, é o modo como o protagonista superpõe seu canto amadorístico à música que emana do fonógrafo.

A pesquisadora María Luisa Ortega, abordando o canto não profissional no musical espanhol El otro lado de la cama (Emilio Martínez Lázaro, 2002), filme em que "as canções são interpretadas por atores sem trajetória ou aura estelar como cantores, por vozes que carecem das qualidades vocais do intérprete profissional" (ORTEGA, 2018, p. 66-67, tradução nossa) ${ }^{8}$, propõe que essas características impõem limites à "excepcionalidade sonora da canção [...] e ligam a escuta à experiencia cotidiana" (ORTEGA, 2018, p. 66-67, tradução nossa) ${ }^{9}$. Fizemos o exercício de imaginar o quanto o sabor específico dessa cena seria alterado caso a música fosse executada em plano extradiegético, soberana e em "primeiríssimo plano" na trilha sonora, sem a voz do protagonista superposta, oferecendo ao espectador a sua "excepcionalidade sonora". Teríamos aí, certamente, mais acesso ao excesso da interpretação virtuosística de Celestino, característica da canção romântica da época, aos detalhes do arranjo e a um grau bem mais elevado de qualidade sonora. Experimentaríamos, pois, o caráter espetacular da canção. Excesso e espetáculo. Melodrama?

Na cena em análise, entretanto, a voz de João Francisco liga a escuta à experiência cotidiana, como disse Ortega, e os efeitos derivados das virtudes expressivas da canção estão substancialmente atenuados pelo modo realista como a música soa, equalizada para parecer que emana de um fonógrafo em ambiente externo, obliterada por ruídos e, principalmente, pela superposição da voz do protagonista, que canta de modo bem informal, sem buscar uma sincronização que carecen de las cualidades vocales del intérprete profesional". 
precisa com a voz de Celestino e sem preocupação rigorosa com a afinação ${ }^{10}$, em um regime próximo ao que Gorbman (2012, p. 23) classificou como canto amador.

Eu chamo tais cenas de um 'canto amador', por falta de outro termo conciso para um canto que, na concepção de uma história de filme, não é um desempenho profissional e é feito com o som sincronizado com índices adequados de realismo espacial, e sem o apoio mágico de uma orquestra. É uma organização da voz no filme que pode parecer marginal, mas pode muito bem contribuir para nossa compreensão das possibilidades da fala, música e canções no cinema.

Gorbman (2012, p. 40) vê esse tipo de canto amador como "uma forma essencial de evocar personagens, subjetividade e inter-relações", ressaltando aproximar-se este de um registro mais realista de uso da canção e do canto no filme, uma vez que são os próprios atores, em cena, que, independentemente de qualquer perfeição técnica na execução, entoam músicas voltadas a expressar sua intimidade e/ou criar ou reforçar vínculos com outro(s) personagem(ns). Segundo ela, o canto amador "é uma performance que partilha dos códigos de realismo e, ao mesmo tempo, raramente é inocente ou sem funções narrativas significativas no filme em que aparece" (GORBMAN, 2012, p. 26).

É a partir da cena do quarto que "Noite cheia de estrelas" assume o protagonismo na narrativa de Madame Satã e entra em cena, sempre em pontos de clímax narrativo e associada ao casal. Essa canção retorna quando, após sair da prisão e saber da morte de Renatinho, João vai tomar um banho de mar. Ele deita na areia, olha para cima e um plano subjetivo nos mostra nuvens densas se movimentando no céu. Parecendo emanar das nuvens, ouvimos a voz de Celestino misturada ao som do vento e aos ruídos do mar. Por breves segundos, a música parece estar em uma dimensão metadiegética, ou seja, parece que estamos ouvindo o que o personagem está a "ouvir" em sua memória. O corte para a cena seguinte revelará que a canção está sendo tocada em um rádio no bar do Amador. 
As últimas duas intervenções de "Noite cheia de estrelas" acontecem pouco tempo depois, na sequência que nos mostra a primeira apresentação em palco de João Francisco. Com um arranjo que a transforma em um choro-canção, a música inteira é interpretada pelo protagonista no show que faz para Laurita no bar do Amador. Durante quase toda a performance, o personagem começa a cantar de modo intimista, quase sussurrando na região médio-grave. Dessa vez, a afinação está perfeita e o arranjo conduz a uma apoteose final em regime espetacular, quando João passa a cantar em falsete, finalizando em fortissimo com um glissando ascendente para a tônica em um registro agudo, numa performance que ele conclui de braços abertos, olhando para o alto, como se a dedicasse à memória daquele para quem cantou essa música no passado (Figura 4).

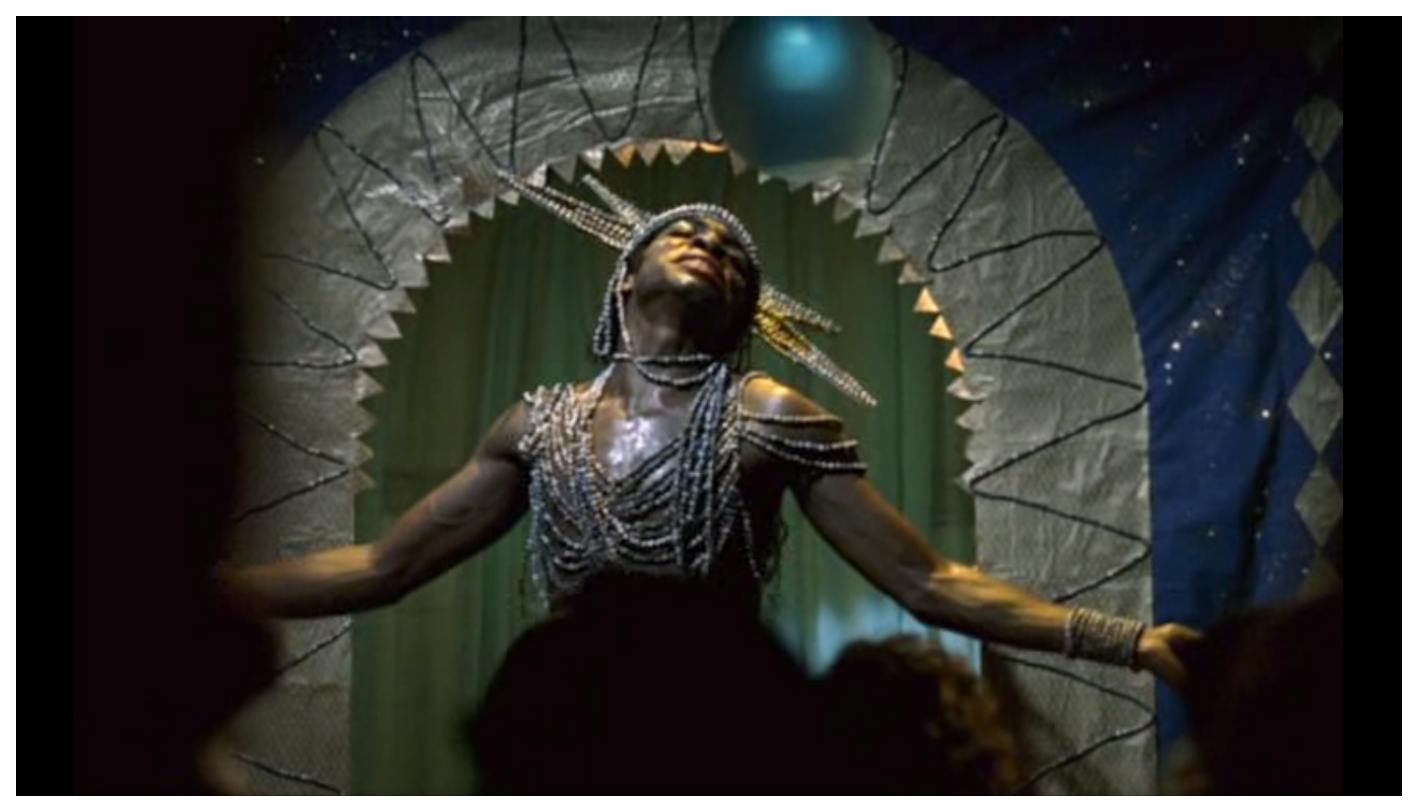

Figura 4: Primeira apresentação em palco de João Francisco Fonte: Madame Satã.

Após os aplausos, um elipse nos leva a um momento em que João Francisco e Amador estão sozinhos, fechando o estabelecimento. Essa cena começa com a última intervenção da canção-tema, desta vez no regime do canto amador e na voz do dono do bar. O cantarolar de Amador, carregado de emoção, e a encenação - planos próximos do rosto do personagem nos permitem enxergar a 
emoção em seus olhos - nos induzem a inferir que o dono do bar também nutre sentimentos paternais (ou até mesmo românticos) por João, pois ele também diz "Quero matar meus desejos/ Sufocá-la com os meus beijos". Eis uma boa evidência empírica de que Gorbman (2012, p. 26) está certa ao dizer que o canto amador é um recurso de natureza realista, mas "raramente é inocente ou sem funções narrativas significativas no filme em que aparece".

Em seu segundo filme com protagonista gay, realizado doze anos depois, o programa cinemusical de Aïnouz sofre uma transformação importante. Enquanto em Madame Satã predominam as canções pré-existentes no plano diegético, em Praia do Futuro a dimensão extradiegética do filme passa a ser ocupada por música instrumental original assinada pelo compositor alemão Volker Bertelmann, mais conhecido como Hauschka, especialista em composição de música para cinema e peças para piano preparado ${ }^{11}$. O projeto, entretanto, também aciona canções e mantém importantes vínculos de estilo com Madame Satã: a natureza transnacional das canções, o recurso ao canto amador superposto a uma canção gravada em momento-chave da progressão dramática do par romântico e a construção da posição político-afetiva do filme em relação ao protagonista.

\section{Donato, Konrad e Christophe: como destroços na areia molhada ${ }^{12}$}

Planos aéreos de dunas e de hélices de captação de energia eólica nos mostram duas pessoas praticando motocross (Figura 5), enquanto ouvimos uma pulsação propulsiva de música eletrônica como acompanhamento de uma voz masculina rascante cantando uma canção em inglês. A música é "Ghost Rider", composta por Martin Rev e Alan Vega e gravada, em 1977, pelo Suicide, duo estadunidense ligado ao movimento electropunk da cena nova-iorquina nas décadas de 1970 e 1980, gênero da música eletrônica que se tornou conhecida também como queercore ou homocore. 


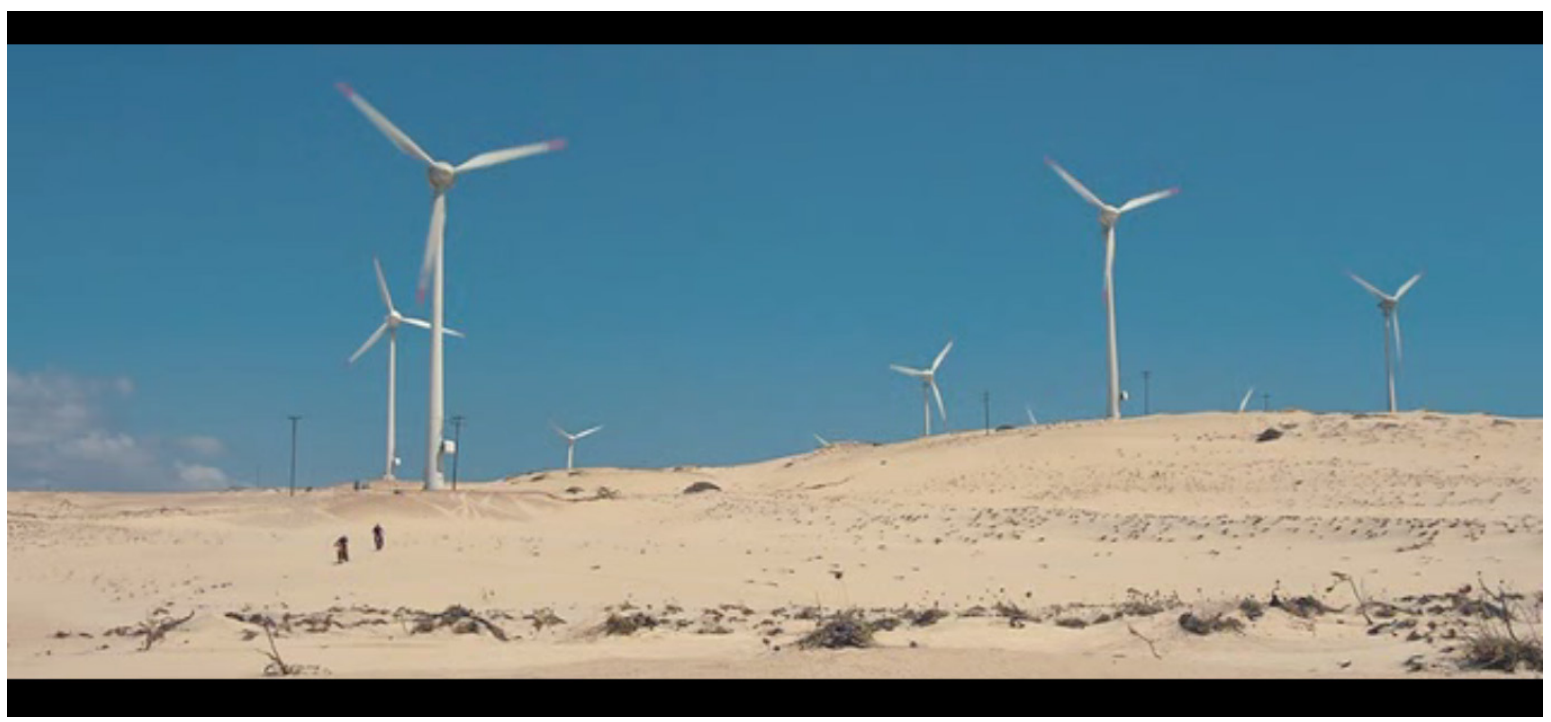

Figura 5: Plano da sequência de abertura de Praia do Futuro

Fonte: Praia do futuro.

Praia do futuro, como já dissemos, investe bem mais do que Madame Satã em música instrumental extradiegética. Composta por Hauschka e executada por violino, violoncelo, guitarra elétrica e piano preparado, essa música, ao longo de todo o filme, afeta a audiência com um páthos suavemente melancólico que adere aos conflitos do protagonista. Para isso, o compositor recorre a tonalidades menores, andamentos lentos, melodias de caráter cantabile e estrutura harmônica triádica com pouco movimento. Essa estratégia começa a ser posta em prática logo no início do filme, na cena em que vemos Donato sozinho, pouco tempo após fracassar no salvamento de um homem.

Desse momento em diante, essa atmosfera musical é convocada em momentos intimistas do protagonista, como, por exemplo, nas imagens subaquáticas dele nadando que encerram a primeira seção da narrativa e nos planos que o mostram caminhando sozinho à noite nas ruas de Berlim, indeciso quanto a ficar na Alemanha ou voltar para o Brasil. Mesmo na cena que nos informa que Donato decidiu ficar em Berlim e, aparentemente, com Konrad, a música mantém um caráter triste, magnificado pela estratégia audiovisual empregada: em uma mise-en-scène que nos mostra o casal dançando em uma casa noturna, todos os sons do espaço fílmico são anulados e o que ouvimos é, mais uma vez, uma música instrumental melódica, 
lenta e em tonalidade menor, parecendo, tal como acontece em Madame Satã, atuar mais aderida ao posicionamento do filme em relação ao protagonista do que ao momento festivo do casal. Como defendem Vitier e Rivero (2008 apud PIEDRAS; DUFAYS, 2018, p. 9, tradução nossa), "expressar a posição dos realizadores perante o que narram"13 é uma das operações que uma canção pode realizar em um filme.

A única vez em que a música apresenta sinais de apaziguamento e esperança em tonalidade maior é no início da cena final, quando os conflitos parecem estar superados e um plano aéreo que rima com a abertura nos mostra duas motos conduzindo Donato, Konrad e Ayrton em uma estrada vazia e nubilosa (Figura 6), para um futuro aparentemente redentor, em uma viagem que nos faz crer na possibilidade de um final feliz para o casal após um tempo de separação e o enfrentamento, por Donato, de tudo aquilo que o impedia de viver plenamente sua relação com Konrad: a aceitação de sua sexualidade por sua família, representada pela reconciliação com seu irmão, e de sua própria fragilidade e falibilidade, expressa no texto epistolar amoroso e de autorreconhecimento que encerra o longa-metragem e aquela parte da jornada do protagonista.

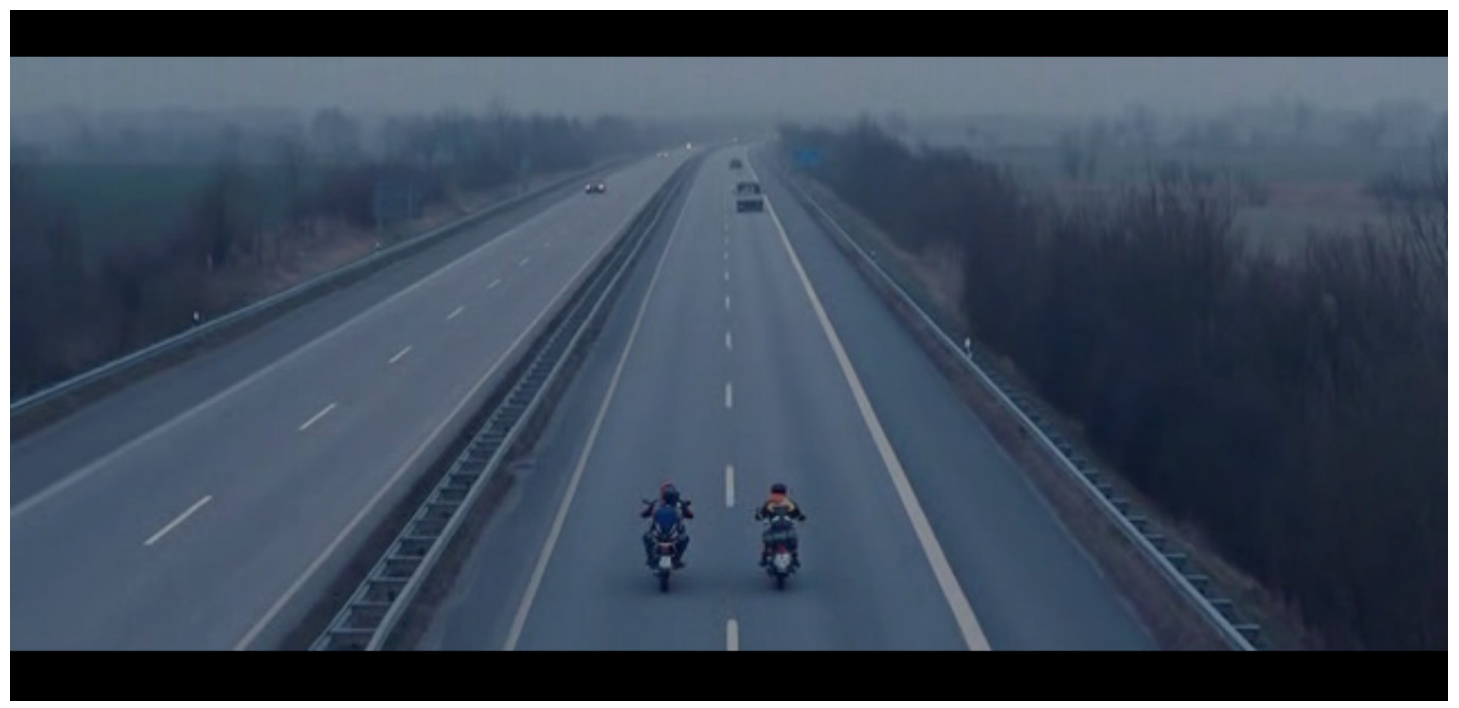

Figura 6: Plano da sequência final do Praia do Futuro

Fonte: Praia do futuro. 
Ao menos na música, a alegria dura pouco. Após um breve desenvolvimento em dó maior, o centro tonal migra para a tonalidade relativa de lá menor, e a mesma atmosfera de desassossego retorna no fim da história, em conjunção com a neblina, a estrada vazia e as palavras de amor fraternal e de reconciliação consigo mesmo do protagonista. Assim, embora a narrativa conclua em um momento redentor de conciliação, a trilha sonora - música e voz over - e as imagens das brumas que envolvem os personagens em muito contribuem para uma percepção de que o filme quer nos dizer que a história dos conflitos não terminou ali. E que a luta é para sempre.

O programa de canções do filme, como vimos, se impõe já na cena de abertura, com uma música que, entre outras coisas, é um signo dos rituais de socialização festiva da cena gay de Nova Iorque. Discutindo questões relacionadas aos processos de identificação que um filme mobiliza nas plateias, Kassabian (2001, p. 2-3) propõe que, no cinema, projetos musicais baseados em compilação de canções estabelecem o que ela chama de affiliating identifications, vínculos com a memória e com o repertório cultural do espectador e laços com associações externas ao filme. Para Ortega, canções populares preexistentes ativam afetos nos espectadores não somente em relação aos personagens e a situações dramatúrgicas, "mas também às intensas relações intertextuais derivadas do reconhecimento de canções e intérprete"14 (2018, p. 67, tradução nossa). Lanin e Caley (2005), citados por Pablo Piedras e Sophie Dufays (2018, p. 9, tradução nossa), dizem que "os efeitos específicos das canções preexistentes procedem de sua qualidade de alusão cultural e intertextual"15. Esses autores nos impelem a interpretar o sintagma audiovisual da abertura de Praia de futuro como uma estratégia de endereçamento da obra à memória de determinado público que reconhece a carga simbólica de "Ghost Rider", dando início a um processo de identificação no espectador implícito na obra. Como veremos a seguir, a música da cena gay da noite de Berlim é um

14 No original: "[...] sino también a las intensas relaciones intertextuales derivadas del reconocimiento de canciones y intérprete". 
dos elementos importantes da paisagem sonora afetiva ${ }^{16}$ (VERNON, 2013, p. 388) transnacional do filme. A canção queercore do Suicide estabelece também outros laços com uma narrativa fortemente marcada pelo tropo dos super-heróis dos quadrinhos, como Aquaman, Speed Racer e Motoqueiro Fantasma, nome que o personagem Ghost Rider recebeu na edição brasileira da revista e que, no filme, é literalmente associado pelo jovem Ayrton a Konrad, por causa de sua moto.

O repertório de canções de Madame Satã tem uma presença forte de sambas e choros, mas tem o tango como canção-tema e música instrumental extradiegética, e a chanson "Nuits d'Alger" como espelho do caráter transnacional da paisagem radiofônica da época em que viveu o João Francisco histórico. Essa natureza transnacional é ampliada no projeto de canções globalizado de Praia do futuro. Os planos iniciais que nos mostram as dunas do Ceará têm como valor acrescentado um signo musical da cena gay nova-iorquina fixado no final do século passado. A paisagem musical multicultural da noite gay berlinense é construída por meio de cenas em casas noturnas onde personagens e espectadores ouvem, por exemplo, a voz da egípcia Fatma Zidan cantando "Yoma" em idioma nativo, acompanhada pelo grupo Oriental Mood, um trio dinamarquês especializado em música turca e de países árabes. Esse projeto de canções globalizado é completado por "Heroes", grande sucesso do inglês David Bowie, que escutamos ao longo dos créditos finais, cantada em inglês e em alemão, e por "Aline", canção romântica composta e interpretada por um francês, produzida por um francês e um italiano ${ }^{17}$, operando como elemento modulador da representação de afetos entre um brasileiro do Ceará e um alemão, em Berlim.

Na história de João Francisco e Renatinho, "Noite cheia de estrelas" empresta seu parnasianismo trágico ao encontro sem final feliz entre João Francisco e Renatinho. Em Praia do futuro, Aïnouz constrói uma cena de afetos e desejos entre Donato e Konrad ao som da canção romântica "Aline", primeiro grande êxito comercial 
internacional do cantor e compositor francês Christophe, lançada em 1965. De forma diferente do que fez em seu longa-metragem de estreia, neste caso, a canção escolhida pelo diretor não se desdobra em canção-tema nem carrega qualquer valor situacional histórico para a narrativa. Há, contudo, importantes pontos em comum entre as duas cenas. Assim como acontece na canção cantada por Celestino, é também uma história dolorosa que o eu lírico de "Aline" nos conta, chorando, gritando e recorrendo à metáfora de destroços de um naufrágio na areia do mar ${ }^{18}$.

"Noite cheia de estrelas" e "Aline" são canções românticas que narram relações amorosas em descompasso, dor e abandono; declarações que não parecem chegar aos ouvidos de suas destinatárias; juras de amor sem efeito e retorno. As palavras das duas canções, assim, se articulam não somente com o momento específico em que são acionadas, mas com o que ocorre de forma mais ampla na narrativa fílmica, uma vez que o afeto e o desejo que os dois casais protagonistas experimentam se transmutam em dor (pela morte de Renatinho enquanto João cumpria pena na cadeia) e abandono (pelo término temporário da relação de Donato com Konrad).

No filme, ouvimos "Aline" logo após a chegada de Donato a Berlim. Vindo do Brasil para viver sua relação com Konrad, este último, na sala do seu apartamento, coloca para tocar a canção de Christophe, que ele acompanha cantando e dançando, performando para seu interesse afetivo de forma divertida e sedutora. Nesta situação, porém, ao contrário do que ocorre com João Francisco em Madame Satã, Donato não foge da demonstração de afeto de Konrad, e sim junta-se a ele para cantar e dançar a chanson (Figuras 7 e 8), em um encontro de corpos repleto de expressões de fisicalidade e virilidade que culminará em mais uma cena de sexo entre os parceiros. disparu/ Et j'ai crié, crié, Aline, pour qu'elle revienne/ Et j'ai pleuré, pleuré, oh! j'avais trop de peine/ Je me suis assis auprès de son âme/ Mais la belle dame s'était enfuie/ Je l'ai cherchée sans plus y croire/ Et sans un espoir, pour me guider/ Et j'ai crié, crié, Aline, pour qu'elle revienne/ Et j'ai pleuré, pleuré, oh! j'avais trop de peine/ Je n'ai gardé que ce doux visage/ Comme une épave sur le sable mouillé". 


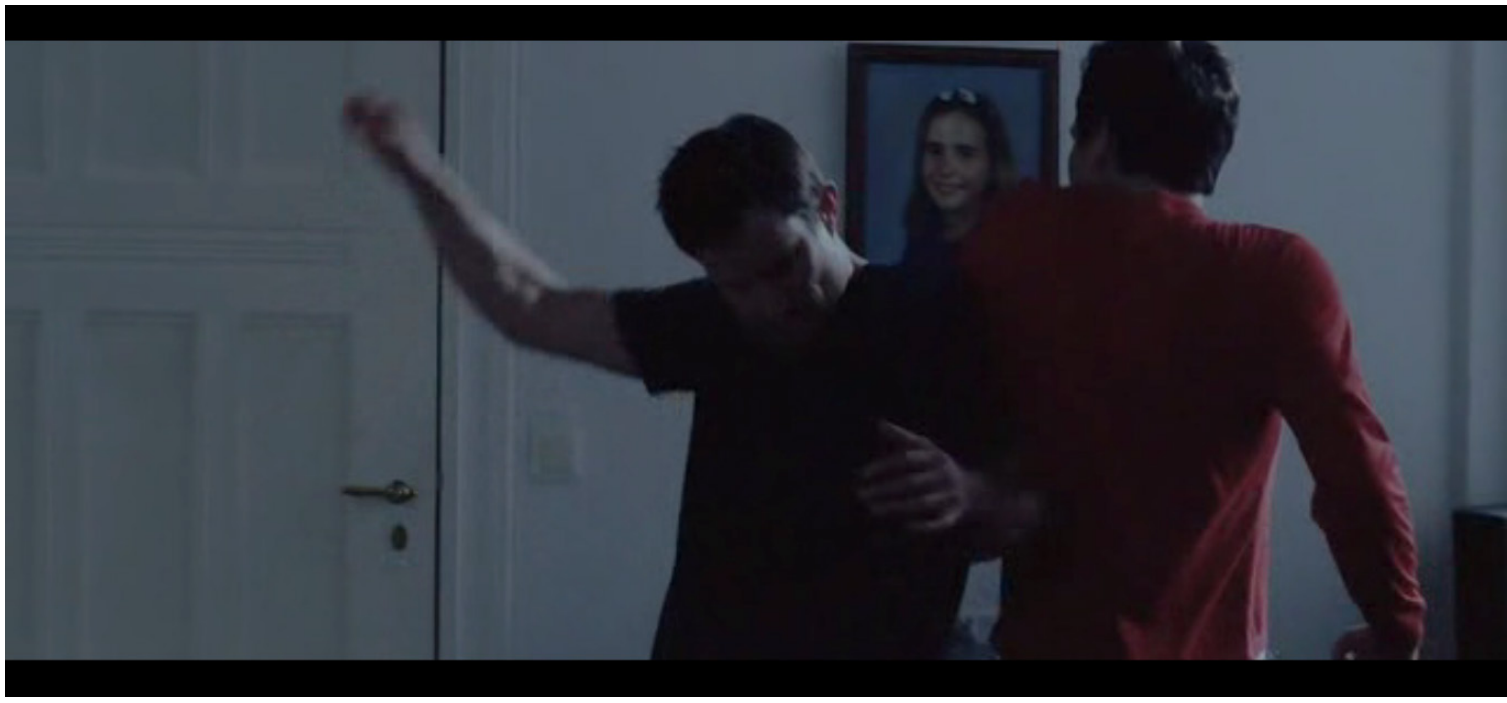

Figura 7: Nonato e Konrad dançam "Aline" Fonte: Praia do futuro.

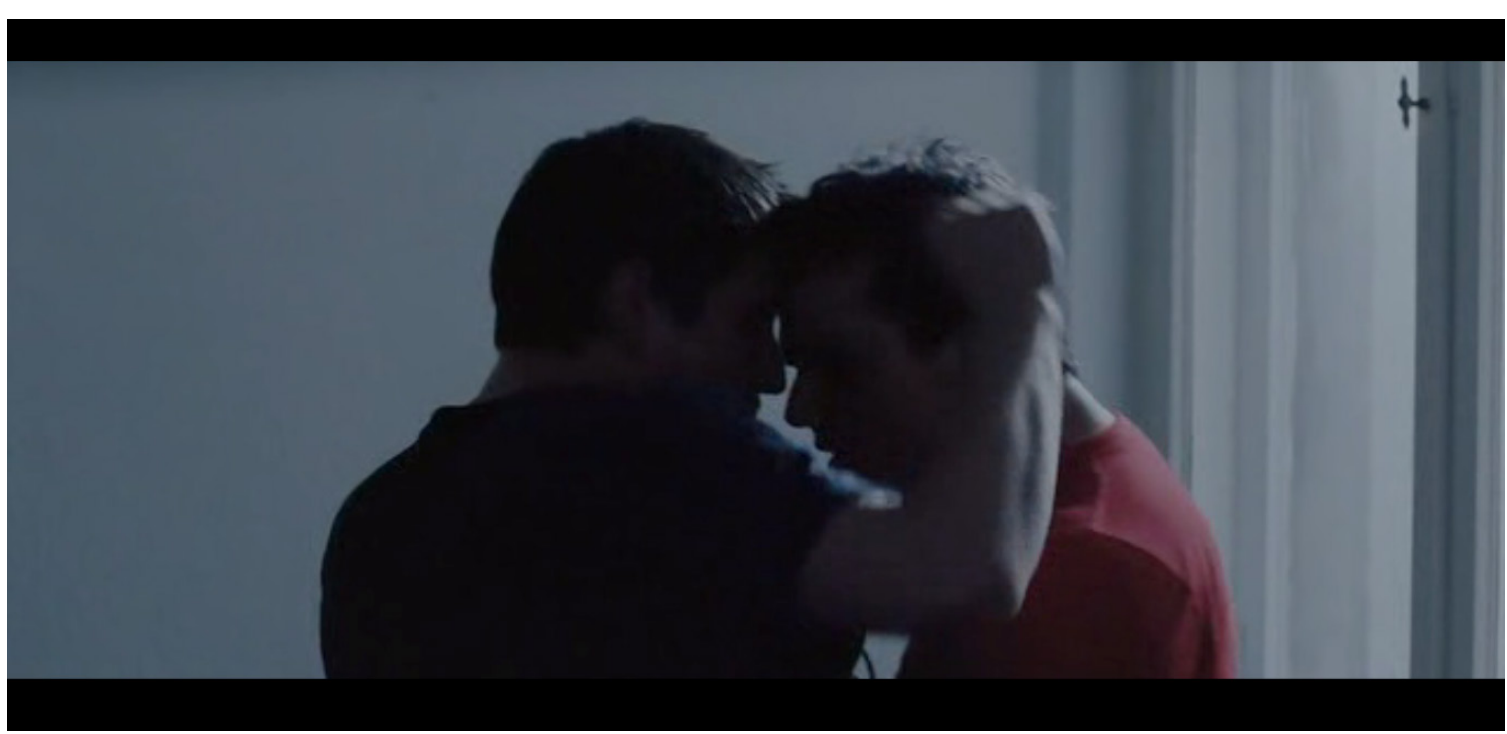

Figura 8: Nonato e Konrad dançam "Aline" Fonte: Praia do futuro.

Se em Madame Satã é o protagonista quem canta para Renatinho, no segundo filme queer de Aïnouz, o canto é assumido pelos dois amantes. Konrad canta acompanhando a primeira parte da gravação de Christophe sozinho, mas Donato logo se junta a ele, em voz e corpo, partilhando desejos em comunhão. Em sintonia com o caráter romântico da melodia de Christophe e da performance do casal, a relação sexual experienciada por eles na cena que sucede imediatamente 
a execução da música é apresentada sem a exploração gráfica do ato sexual em si - focada apenas nos beijos e carícias trocados -, em um ambiente doméstico e totalmente privado - a casa de Konrad (Figura 9) -, ao contrário da primeira relação mostrada no filme, em que o ato sexual é mostrado de forma mais explícita e carnal - com ênfase na penetração de Donato por Konrad, sem troca de beijos ou carícias entre eles - em um ambiente praticamente público - dentro do carro de Donato, estacionado à beira de uma avenida (Figura 10).

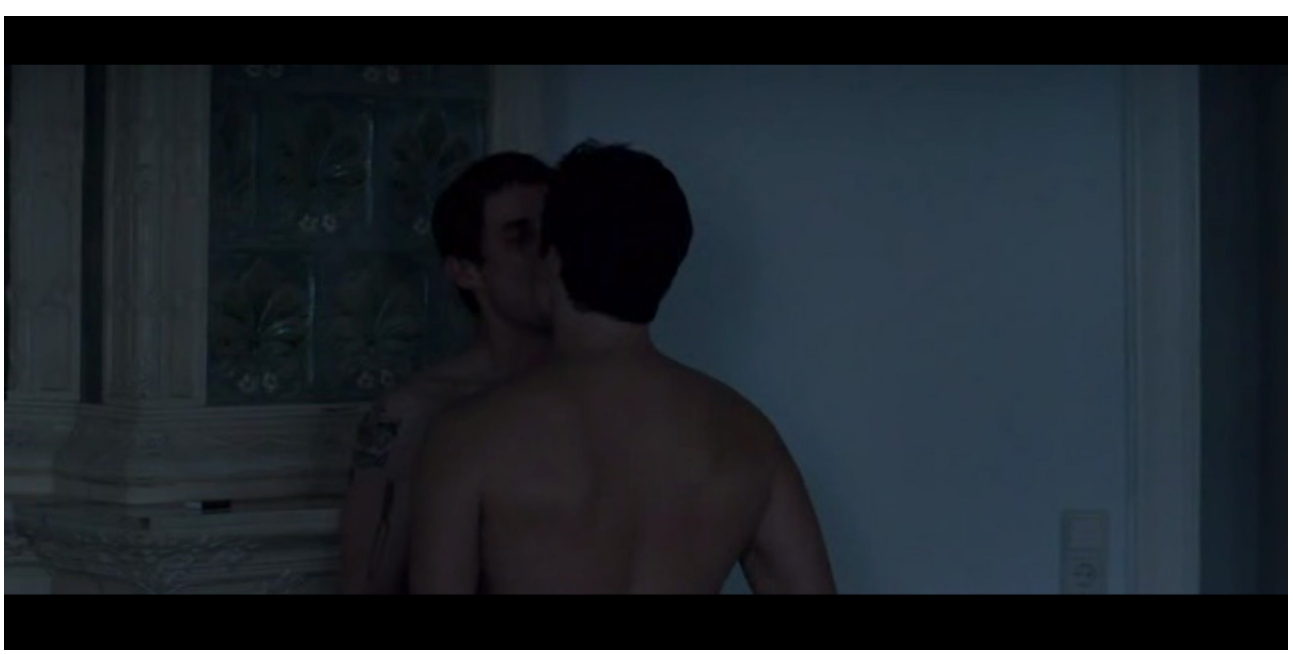

Figura 9: O ato sexual na casa de Konrad Fonte: Praia do futuro.

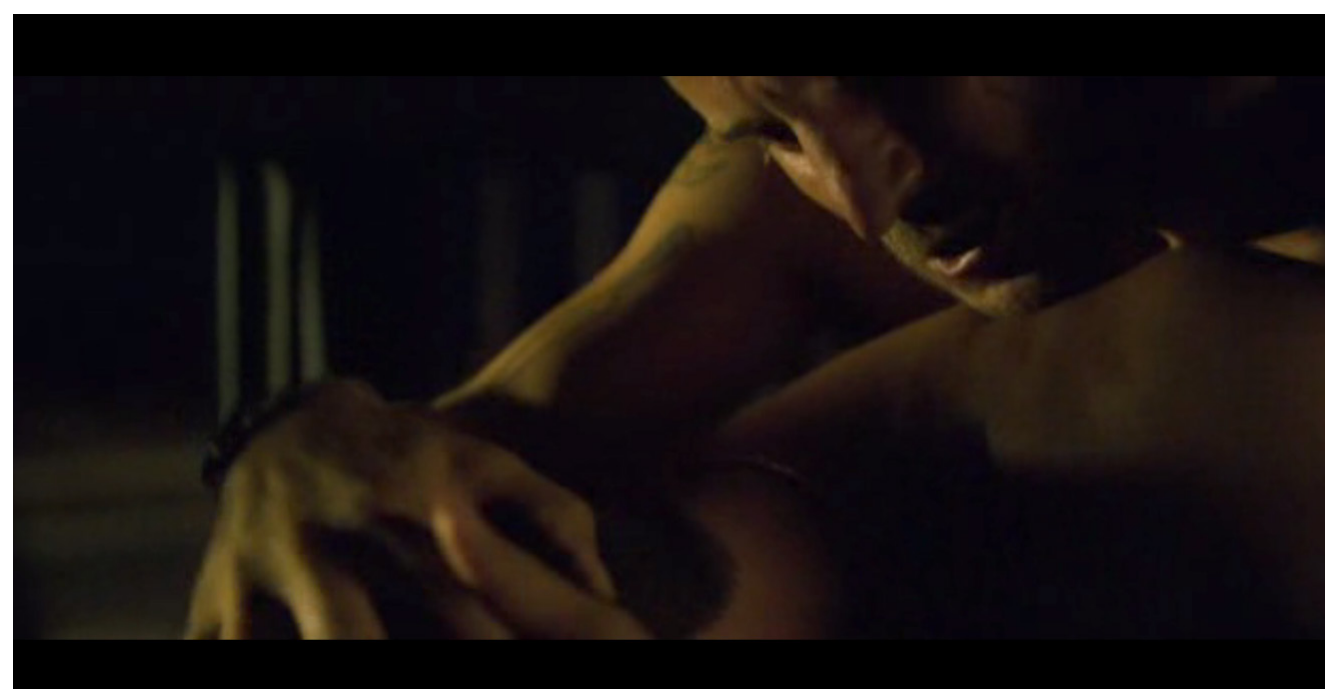

Figura 10: $O$ ato sexual no carro

Fonte: Praia do futuro. 
Na nossa análise das operações de "Noite cheia de estrelas" em Madame Satã, propusemos que a superposição do canto amador, fora de sincronismo e da tonalidade da gravação, ao "borrar" as estratégias de encanto intrínsecas à canção, inscreve a cena em um regime realista que liga a escuta ao cotidiano e se afasta do melodrama. Já na cena em que Donato e Conrad dançam e cantam "Aline", essa estratégia também está em jogo no início da cena, mas agora em uma chave que tem um toque de comicidade, derivada do evidente exagero na interpretação de Konrad. Esse pathos descontraído e alegre permanece quando Donato entra em quadro cantando e dançando a segunda estrofe da canção junto com Konrad. Após a primeira exposição completa da canção, no entanto, o canto amador do casal fica mais rarefeito e a voz romântica de Christophe explode em primeiro plano na trilha sonora, despejando romantismo sobre as imagens que nos mostram corpos que dançam, brincam de luta, sorriem e trocam carícias.

\section{A música e a potência política dos corpos}

Segundo a pesquisadora Geisa Rodrigues (2011, p. 140), até o fim da década de 1990, as representações de Madame Satã caminhavam, via de regra, em três sentidos:

o personagem como representante da memória do Rio de Janeiro (Lapa, malandragem, boemia e samba compondo este universo); a abordagem a partir da 'peculiar' combinação homossexual/valente; e o seu papel como representante de um universo marginal e excluído, em particular a partir da experiência da prisão.

Para Rodrigues (2011, p. 140), o filme de Aïnouz marca um ponto de virada nas representações do personagem histórico "principalmente por revelar uma potência política para seu corpo pouco explorada até então". Mais aderido a um compromisso com a representação realista em Madame Satã e mais próximo do artifício em Praia do futuro, os projetos musicais dos dois filmes são recursos importantes na estratégia de composição audiovisual dessa potência, pela via do afeto. As versões instrumentais de "Nuits d'Alger" e "Tango romântico" soam, 
em Madame Satã, como a voz do filme declarando a empatia da obra com o seu personagem e solicitando a aderência afetiva do espectador em relação a João Francisco. Donato, igualmente, é acompanhado, em sua trajetória dramatúrgica, por uma música suave, melódica e melancólica que manifesta claramente o posicionamento político-afetivo do filme em relação à relevância simbólica do seu protagonista. Além disso, nos dois casos, fica claro que a estética queer de Karim Aïnouz não rejeita o "melo" do melodrama, ou seja, não rechaça o artifício de utilizar a música extradiegética para representar subjetividades e construir o vínculo afetivo entre o espectador e o protagonista.

Nas duas obras, as canções desenham uma paisagem midiática transnacional, buscando estabelecer uma "identidade coletiva e relações intertextuais que vinculam diferentes tempos, geografias e culturas"19 (ORTEGA, 2018, p. 79, tradução nossa). Canções são chamadas à causa em momentos nos quais a potência política dos corpos aparece em relevo na encenação. Propusemos que, na cena no quarto de João Francisco, o canto amador opera interditando o exagero e o espetáculo próprios do modo de usar canções nos melodramas. Já no apartamento de Konrad em Berlim, quando a voz de Christophe passa a ocupar o primeiro plano, os excessos românticos de "Aline" ocupam o proscênio. Em Madame Satã, entretanto, a mesma canção romântica que soa borrada pelo canto amador e pelos sons ambientes nas cenas do quarto e da praia vai explodir em espetáculo audiovisual no primeiro número musical de João Francisco no palco.

Moldados com aderência às premissas do New Queer Cinema, Donato e João Francisco são seres de linguagem ambíguos, contraditórios, em conflito. Na tela e nos alto-falantes, João e Donato são corpos, afeições e desejos transgressores, representações audiovisuais de identidades e experiências queer complexas que rechaçam as simplificações redutoras do personagem-tipo. A música dos dois filmes, envolvendo, em uma mesma rede de afetos, a obra, os protagonistas e o espectador, é um valor acrescentado que convoca o fruidor a "colar" nos 
personagens e celebrar a identidade queer, em um regime no qual estratégias musicais realistas e melodramáticas trabalham lado a lado como "veículos de emoção e de afetos, instrumentos de identificação e de distanciamento, vetores de alusão cultural, catalisadores de memórias individuais e coletivas" (PIEDRAS; DUFAYS, 2018, tradução nossa)20. Decerto, não foi à toa a escolha de "Heroes", de David Bowie, para os créditos finais de Praia do futuro.

\section{Referências}

BORDWELL, D. Narration on fiction film. Madison: University of Wisconsin Press, 1985.

BRESSON, R. Notas sobre o cinematógrafo. São Paulo: Iluminuras, 2005.

CHAUVIN, I. D. Ter saudade até que é bom. Música y afectividad en dos documentales brasileños recientes. 4520 $F$, Barcelona, n. 14, p. 45-68, 2016.

CHION, M. Audio-vision. Nova Iorque: Columbia University Press, 1993.

COLLIER, S. Carlos Gardel: su vida, su música, su época. Santiago: Ariadna, 2003.

GORBMAN, C. O canto amador. In: SÁ, S. P. de; COSTA, F. M. (org.). Som + imagem. Rio de Janeiro: 7Letras, 2012. p. 23-41.

KARIM Aïnouz. In: IMDB. [S. I.: s. n.], [2019]. Disponível em: https://imdb.to/2zzg87H. Acesso em: 15 fev. 2019. 
KASSABIAN, A. Hearing film: tracking identifications in contemporary Hollywood film music. Nova Iorque: Routledge, 2001.

LACERDA, C. New Queer Cinema e o cinema brasileiro. In: MURARI, L.; NAGIME, M. (org.). New Queer Cinema: cinema, sexualidade e política. São Paulo: Caixa Econômica Federal, 2015. p. 122-127.

MADAME Satã. Direção: Karim Aïnouz. Rio de Janeiro: Video Filmes, 2002. 1 vídeo (105 min).

ORTEGA, M. L. Los paisajes afectivos de la cancíon en el cine español del siglo XXI. In: PIEDRAS, P.; DUFAYS, S. (org.). Conozco la canción: melodías populares en los cines posclásicos de América Latina y Europa. Buenos Aires: Libraria, 2018. p. $65-88$.

PIEDRAS, P.; DUFAYS, S. (org.). Conozco la canción: melodías populares en los cines posclásicos de América Latina y Europa. Buenos Aires: Libraria, 2018.

PRAIA do futuro. Direção: Karim Aïnouz. São Paulo: Coração da Selva, 2014. 1 vídeo (106 $\mathrm{min})$.

RICH, B. R.. "New Queer Cinema: versão da diretora". In: MURARI, L.; NAGIME, M. (org.). New Queer Cinema: cinema, sexualidade e política. São Paulo: Caixa Econômica Federal, 2015, p. 18-29.

RODRIGUES, G. Madame Satã: desconstruindo a cena. Terceira Margem, Rio de Janeiro, n. 24, p. 139-160, 2011.

TRIER, L. von; VINTERBERG, T. Dogma 95. Copenhague: [s. n.], 1995. Disponível em: https://bit.ly/2ZOggL3. Acesso em: 12 jun. 2019. 
VERNON, K. M. Almodóvar's Global Musical Marketplace. In: D'LUGO, M.; VERNON, K. M. A companion to Pedro Almodóvar. Oxford: Blackwell, 2013. p. 387-411.

Submetido em: 3 jul. 2019 | aprovado em: 22 nov. 2019 